\title{
Variation in fold geometry in the Yuso Basin, northern Spain: implications for the deformation regime
}

\author{
Ben A. van der Pluijm \\ Department of Geological Sciences, University of Michigan, 1006 C.C. Little Building, Ann Arbor, MI 48109, \\ U.S.A. \\ JoHN F. SAVAGE \\ Institute of Earth Sciences, University of Utrecht, PO Box 80.021, 3508 TA Utrecht, The Netherlands \\ and \\ Caspar H. KaARs-SiJPesteijn \\ c/o Shell Internationale Petroleum Maatschappij BV, PO Box 162, 2501 AN Den-Haag, The Netherlands
}

(Received 10 April 1985; accepted in revised form 16 March 1986)

\begin{abstract}
First generation structures in greywackes of the Yuso Group from the Cantabrian Mountains of northern Spain show a distinct variation in geometry with depth in a regional synclinal structure (Curavacas and Lechada synclines); they are easily distinguished from other deformation events. In the structurally uppermost level we find 'flap folds'. Flap folds are recumbent structures with the inverted limb preserved. Below this level 'cascade folds' are found. These structures have a vergence opposite to that of parasitic folds. The nomenclature adopted is from Harrison and Falcon. Characteristically, these structures have shallowly dipping axial surfaces, in agreement with the shallow dip of the axial plane (regional) cleavage. In the lowermost structural level, upright parasitic folds with a steep cleavage are present. The variation in fold geometry is accompanied by a general steepening of the regional cleavage with increasing depth. In the absence of overprinting relationships the $F_{1}$ fold geometries are included in a single deformation event.

The steepening of the cleavage with depth reflects the change in orientation of the maximum shortening direction from sub-vertical in the upper part of the syncline to sub-horizontal in the lower part. With increasing depth the deformation regime during $F_{1}$ changed from bending to buckling. The deformation regime on the regional scale, however, is associated with basement subsidence and passive formation of the regional synclinal structure. Furthermore, the absence of a distinct microfabric for the different $F_{1}$ folds indicates that on a small scale a similar deformation regime was present. We conclude, therefore, that the scale at which we study a structure only reflects the deformation regime at that particular scale. Consequently, the overall deformation regime cannot be determined from single outcrops or microstructural analysis alone.
\end{abstract}

\section{INTRODUCTION}

The Cantabrian Mountains of northern Spain form part of the Hercynian Belt in Europe. Hercynian deformation in this area took place in Upper Palaeozoic times and involved thrusting, folding and strike-slip faulting of units ranging in age from Precambrian to Upper Carboniferous (e.g. Julivert 1971, Wagner \& MartinezGarcia 1974, Savage 1979).

The rocks discussed in this paper belong to the Yuso Group (Koopmans 1962), which yielded Westphalian age fossils (van Ginkel 1965). A comprehensive review of the stratigraphy and the geology of the southern Cantabrian Mountains is given in Savage \& Boschma (1980). Upper Carboniferous sedimentation took place in rapidly subsiding basins that are considered to be associated with a continental strike-slip system (Arthaud \& Matte 1977, Heward \& Reading 1980).

The Yuso Group consists of a thick conglomerate unit at the base (Curavacas Conglomerate; Oriol 1876, Kanis
1956), a greywacke unit (Lechada Formation; van Veen 1965, Savage 1967, Reading 1970, Maas 1974) and near the top, locally, a thin limestone unit (El Ves Limestone, Panda Limestone; van Veen 1965, Savage 1967).

In the Yuso Basin, comprising the Curavacas and Lechada synclines (Fig. 1), folding is the dominant deformation structure and is most common in the Lechada Formation. The area of Fig. 1 was mapped in detail by van Veen (1965), Savage (1967), KaarsSijpesteijn (1981) and van der Pluijm (1981). The unusual geometries of folds associated with the oldest tectonic deformation generation, $F_{1}$, have only been reported from one other area (Iran; Harrison \& Falcon $1934,1936)$. In addition, $F_{1}$ shows a systematic variation in fold style and orientation with respect to the structural level in the regional synclinal structure. A welldeveloped axial-plane cleavage ( $S_{1}$, regional cleavage) is associated with these folds. In this paper the development and significance of these folds is examined in view of the basin history and the deformation regime. 


\section{DEFORMATION GENERATIONS}

Three events of folding have been recognized in the area. A brief description of pre- $F_{1}$ folding and $F_{2}$ folding will be given to demonstrate that the different $F_{1}$ fold geometries observed comprise a single deformation event rather than multiple events.

The total deformation history consists of two tectonic deformation generations $\left(F_{1}\right.$ and $\left.F_{2}\right)$ and one synsedimentary event. Two cleavages $\left(S_{1}\right.$ and $\left.S_{2}\right)$ have been recognized and overprinting relationships of slump folds and $F_{1}$, and $F_{1}$ and $F_{2}$ are present. The hard-rock nature of both $F_{1}$ and $F_{2}$ is demonstrated by the presence of $S_{1}$ cleavage and $F_{2}$ folds in deformed felsic dykes. This conflicts with the earlier interpretation of $S_{1}$ as a dewatering cleavage (Lobato Astorga 1977).

\section{Syn-sedimentary deformation}

Slump folds, associated with disrupted bedding, are common in the greywackes of the Lechada Formation. These structures are usually confined to horizons up to several metres thick and traceable for hundreds of metres. The zones are truncated at top and bottom by (pre- $F_{1}$ ) undisturbed sandstone-shale alternating layers. An example of part of a slump horizon from the Curavacas syncline with the characteristic syn-sedimentary deformation is shown in Fig. 2(a).

Slump folds cannot be distinguished from hard-rock folds on the basis of morphology alone (see for example Hobbs et al. 1976, p. 156). In particular, distinction may be difficult when superimposed deformation is intense and the structures have become attenuated. Locally, for example in the core of the Curavacas syncline, folds with an axial-plane cleavage are present in slump horizons, but it is not possible to conclude whether the cleavage formed during folding (compare Williams et al. 1969, Tobisch 1984), or as a result of $\left(F_{1}\right)$ deformation superimposed co-axially on the slump folds. In other parts of the area the regional cleavage $\left(S_{1}\right)$ can be shown to post-date similar structures.

Other evidence for slumping in the area is the occurrence of large blocks (olistoliths) cutting across regional strike; for example, a limestone block of approximately $60 \mathrm{~m}$ in thickness in the Lechada syncline (Fig. 1). Many other examples have been documented from nearby areas (Maas 1974, Maas \& van Ginkel 1983).

\section{Second deformation generation}

Relatively narrow zones, tens of metres wide, displaying intense deformation are present throughout the area. Within these zones asymmetrical kink folds of both bedding and $S_{1}$ cleavage are found (Fig. 2c) and, locally, overprinting relationships between $F_{1}$ and $F_{2}$ folds have been recognized. In the hinges of $F_{2}$ folds a kink cleavage $\left(S_{2}\right)$ has developed.

The $F_{2}$ deformation zones are associated with late high-angle faults, for example along the Peñas Matas Fault (Figs. 1 and 4). The $F_{2}$ folds in these zones are easily distinguished from $F_{1}$ structures by the presence of kink folds of the regional cleavage and their restricted occurrence in deformation zones.

The $F_{2}$-related Peñas Matas Fault is responsible for the present map pattern (Fig. 1). Prior to faulting the Curavacas and Lechada synclines comprised a single west-plunging syncline (Savage 1967).

\section{First deformation generation}

Structures associated with the first tectonic deformation event show a large variation in style and orientation. They are identified on the basis of their relationship to the regional cleavage (axial plane cleavage to $F_{1}$ folds), and overprinting relationships with distinctly different pre- $F_{1}$ and $F_{2}$ folds. Overprinting relationships between the various $F_{1}$ fold geometries were not observed and they were, therefore, included in one single deformation generation.

In view of the distribution of the various $F_{1}$ fold geometries, $F_{1}$ folds from the Curavacas and Lechada synclines, and their relationship to the regional structure, will be discussed in separate sections below.

Curavacas syncline. $F_{1}$ folds in the Curavacas syncline are tight to isoclinal, with steeply north dipping axial surfaces and a well-developed axial-plane cleavage $\left(S_{1}\right)$. They are parasitic to the large synclinal structure, for example the $F_{1}$ fold in Fig. 2(b) from the northern limb of the Curavacas syncline. The fold vergence indicates a synclinal closure to the south, in agreement with the regional structure. The orientation of $F_{1}$ fold axes varies considerably (Fig. 3); however, the great-circle distribution corresponds well with the average $S_{1}$ cleavage orientation, which trends approximately east-west with a dip angle of $55^{\circ}$ to the north (modal $S_{1}: 010^{\circ} / 55^{\circ}$ ).

In cross-section III of Fig. 4 the synclinal structure and its relationship with $S_{1}$ cleavage are illustrated. The Curavacas syncline is a near isoclinal, overturned, syncline with a shallowly west plunging axis. While $S_{1}$ appears to be approximately axial planar to the syncline, aberrant relationships are found on the south limb. The cleavage, locally, has a dip which is less than that of bedding, resulting in downward structural facing directions (Borradaile 1976), while bedding youngs upward. This indicates that the cleavage is not associated with the development of the synclinal structure. The beddingcleavage intersection, however, still yields a concentration around the major fold axis (Savage 1967).

Lechada syncline. The Lechada syncline lies west of the Penas Matas Fault (Fig. 1). It is a comparatively open structure with a significantly larger interlimb angle than the Curavacas syncline. The regional cleavage is flat-lying (van Veen 1965, Savage 1967) and is clearly not axial planar to the large structure. The type section of concentric cleavage, as designated by de Sitter (1964, p. 292), is in this area.

Cross-sections I and II through the syncline (Fig. 4) show that on both limbs the cleavage dip is less than that 


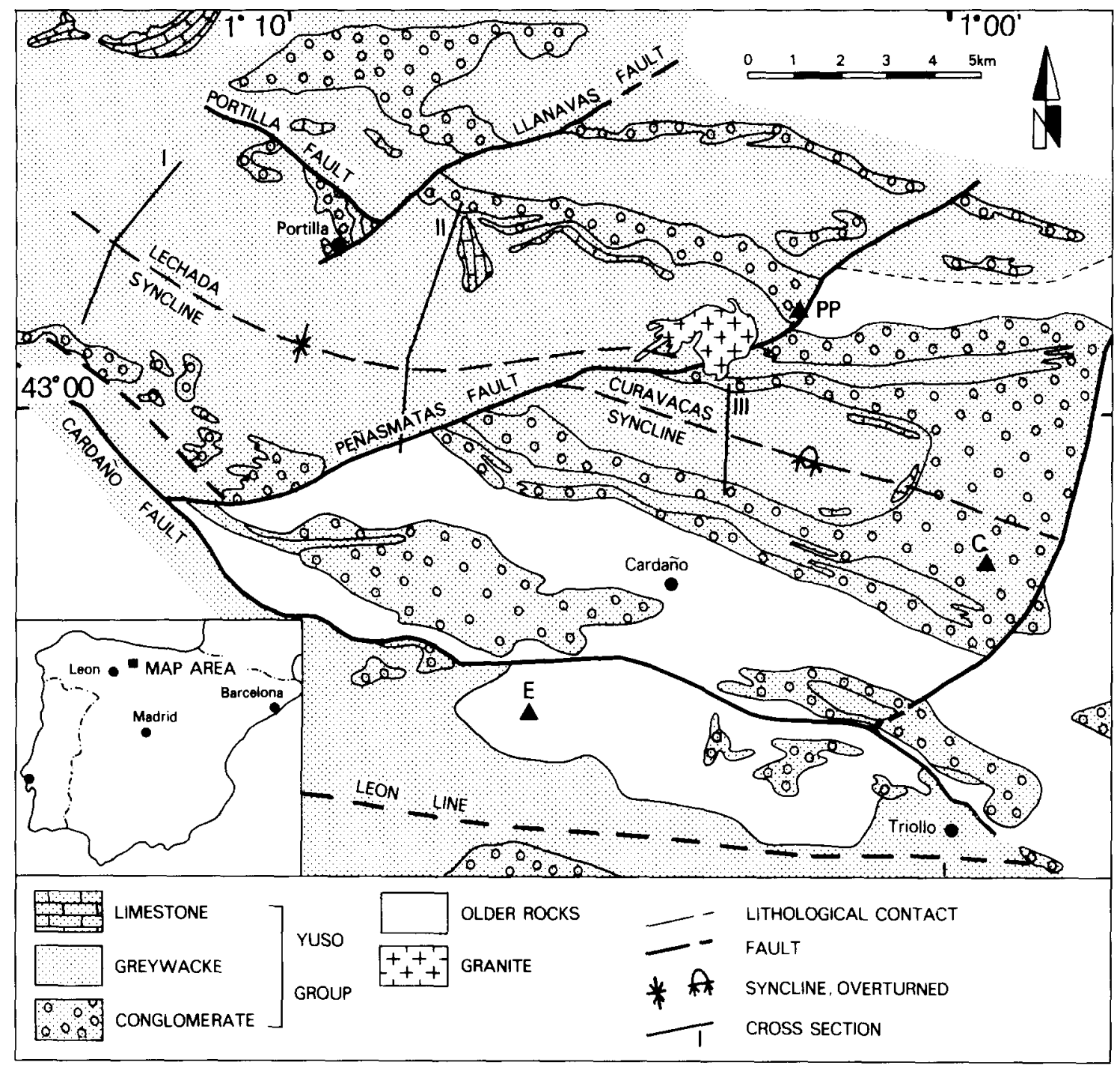

Fig. 1. Generalized structural map of the Yuso Basin and surrounding area. Abbreviations used for mountain peaks are: C, Curavacas; E, Espiguete; PP, Peña Prieta. Mapping by the authors and van Veen (1965). 

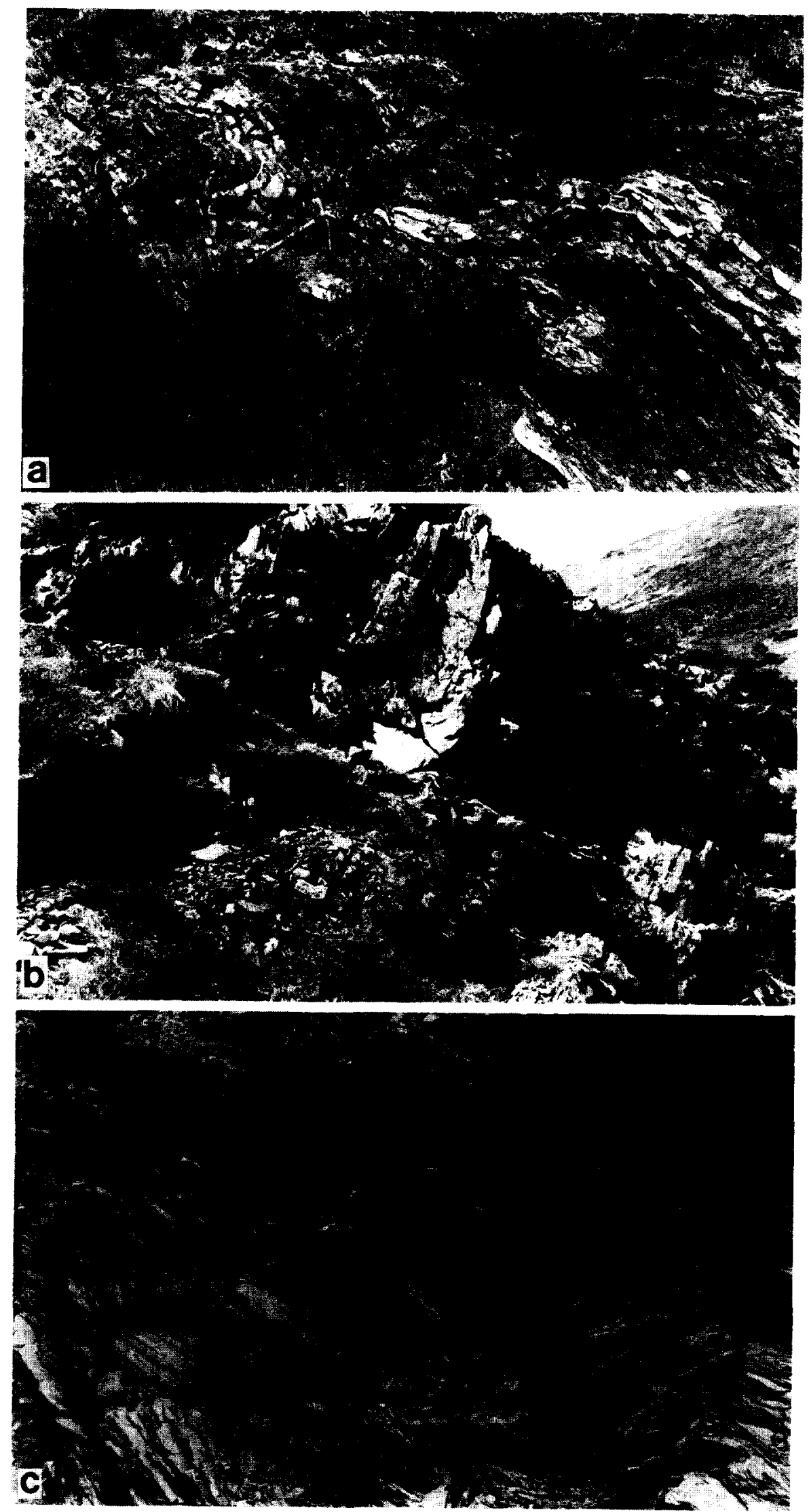

Fig. 2. Photographs of structures representative of the three deformation events in the Carboniferous Yuso Basin. (a) Part of a slump horizon in the southern part of the Curavacas syncline. Note the disruption and folding of bedding (near hammer). Hammer is approximately $30 \mathrm{~cm}$ long. (b) $F_{1}$ parasitic fold with characteristically well-developed axial plane cleavage $\left(S_{1}\right)$ from the northern part of the Curavacas syncline; width of image is $8 \mathrm{~m}$. (c) Part of an $S_{2}$ deformation zone, $1.5 \mathrm{~km}$ south of Triollo; width of image is $8 \mathrm{~m}$. 


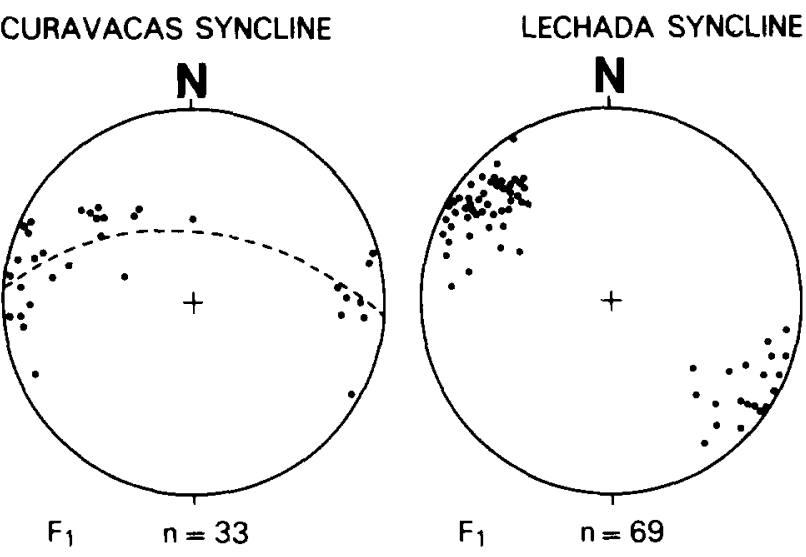

Fig. 3. Lower hemisphere equal-area projections of $F_{1}$ fold axes from the Curavacas and Lechada synclines. Number of measurements $(n)$ is indicated. of bedding. In addition, the cleavage becomes increasingly more flat-lying toward the west. Only in the core of the syncline has a steeply dipping cleavage been observed. A variety of $F_{1}$ folds are present, all with the flat-lying cleavage as axial planar; two examples are given in Fig. 5. The orientation of $F_{1}$ axes (Fig. 3) is consistent with the trend of the Lechada syncline (Fig. 1).

The $F_{1}$ minor fold geometries of the Lechada syncline are similar to structures reported in limestones from Iran by Harrison \& Falcon $(1934,1936)$. They distinguished three types of structures, schematically shown in Fig. 6: (1) cascade folds, (2) flap folds and (3) slip sheets (see also de Sitter 1964). Combined, they are grouped as gravitational collapse structures since gravity is believed to be the driving force. de Sitter (1964), however, noted that these structures may have been accentuated by recent gravitational collapse, but that they were originally formed in an earlier stage, possibly below surface level.
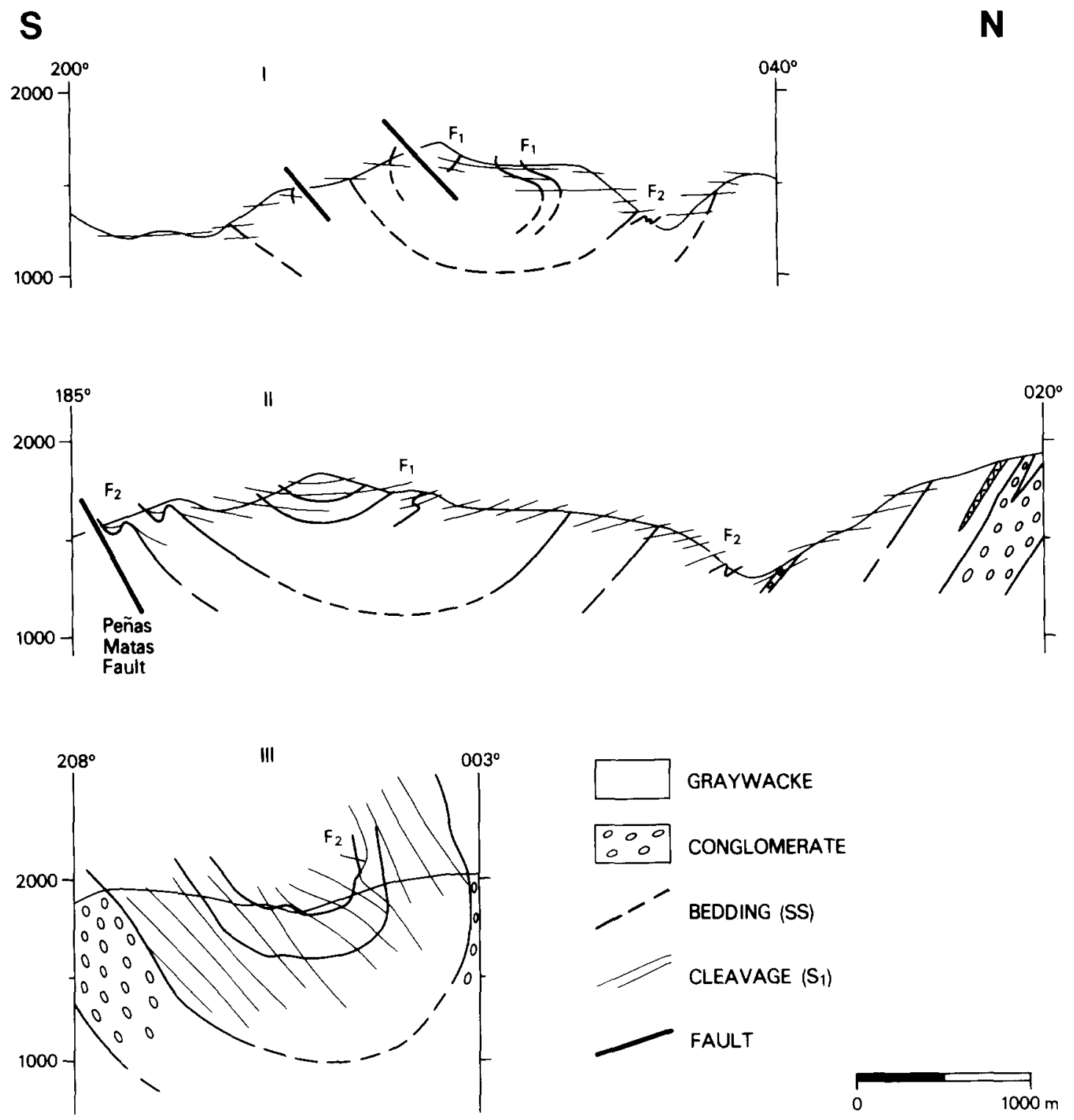

Fig. 4. Cross-sections through the Lechada (I and II) and Curavacas (III) synclines. Locations of the sections are shown in Fig. 1. 


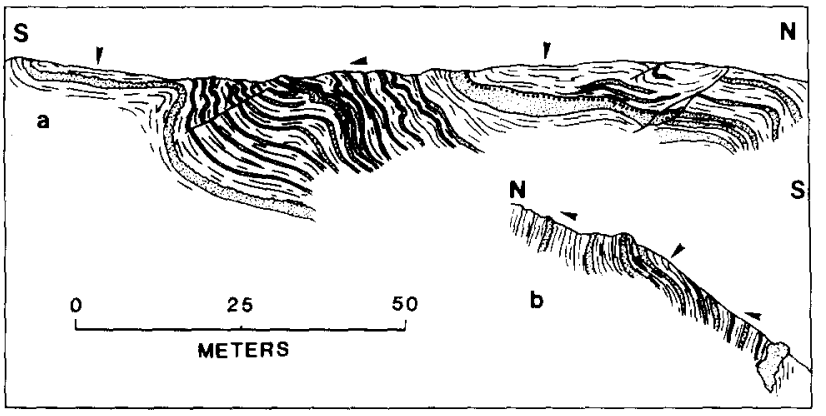

Fig. 5. Field sketches of a flap fold (a) and a cascade fold (b) from the Lechada syncline. Younging directions are indicated by arrows (redrawn from Savage 1967).

In the Lechada syncline cascade folds are minor folds with a vergence opposite to that of parasitic folds; they are up to several tens of metres in size (Fig. $5 b$ ) and relatively common. Flap folds are larger scale structures (limbs up to $500 \mathrm{~m}$ ) with the inverted, flat-lying limb preserved (Fig. 5a). The third type of structure, slip sheets, has also been recognized (Savage 1967).

The $F_{1}$ fold types have a distinct distribution in the area. Flap folds are restricted to the western part and, therefore, highest structural level of the west plunging syncline. Cascade folds, on the other hand, are found in the eastern part of the Lechada syncline and, therefore, at a relatively lower structural level. This relationship is schematically illustrated in Fig. 7. Maas (1974; see also Heward \& Reading 1980) has suggested a parasitic relationship between these two fold types; however, this is not confirmed by our observations.

Summary of $\mathrm{F}_{1}$ fold characteristics. The occurrence of $F_{1}$ minor structures in the Yuso Basin is controlled by the relative level in the regional syncline. From upper to lower structural levels (i.e. from west to east) we find flap folds, cascade folds and parasitic folds (Fig. 7). This variation is accompanied by a general steepening of the $S_{1}$ cleavage with depth, which remains axial planar to the $F_{1}$ folds throughout the map area.

\section{DISCUSSION}

The Curavacas and Lechada synclines have their origin in a rapidly subsiding narrow depression, which

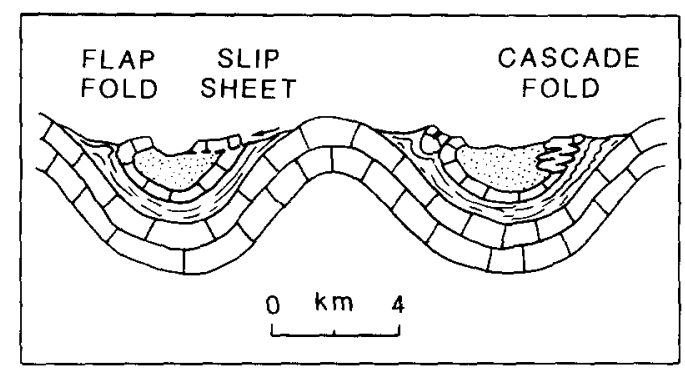

Fig. 6. Composite diagram showing structures observed in Iran by Harrison \& Falcon $(1934,1936)$ and their classification.

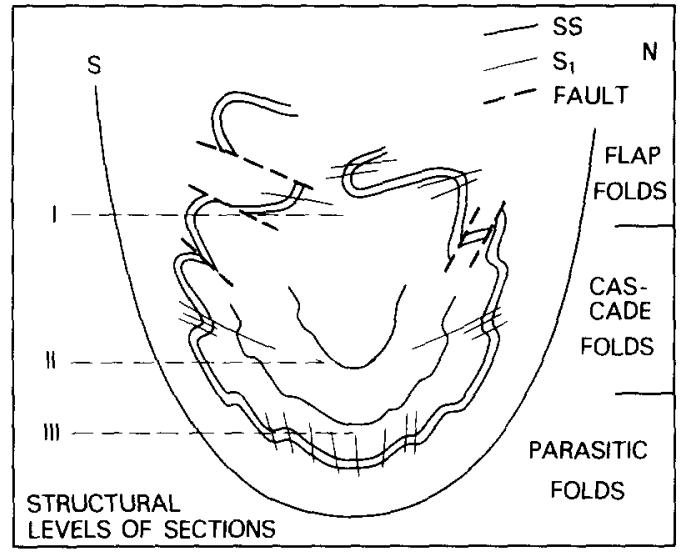

Fig. 7. Schematic illustration of the different $F_{1}$ fold types and their relative structural level in the syncline. The orientation of $S_{1}$ is also included (modified from Savage 1967)

received a large amount of sediment (approximately $2000 \mathrm{~m}$ ) in a relatively short time interval in Upper Carboniferous times (sedimentation rate is $0.4 \mathrm{~m} / 1000$ years; van Veen 1965, Savage 1967, Lobato Astorga 1977). The presence of slump horizons in the stratigraphic sequence indicates deposition on an unstable slope. The $F_{1}$ structures described in this paper have developed on this sedimentary pattern. The original Yuso Basin presently comprises two synclines, separated by an $F_{2}$-related high-angle fault (Fig. 1).

The first tectonic deformation generation is represented by a variety of structures and above we established a relationship between $F_{1}$ fold geometry and structural level in the syncline (Fig. 7). On the limbs of both synclines $S_{1}$ cleavage dip is less than that of bedding, when the overturned north limb of the Curavacas is restored to an upright position. In other words, downward-facing directions (Borradaile 1976) are present on the limbs of both synclines. In addition, we find a gradual change in the angle between bedding and cleavage. In the most westerly part of the area the angle between bedding and cleavage is relatively large, and decreases toward the east. In the Curavacas syncline the angle is less than $10^{\circ}$.

In the core of the Curavacas syncline a different relationship is present. Here, the cleavage appears to be axial planar to the large structure, resulting in upwardfacing directions. In the Lechada syncline, on the other hand, the cleavage is still dominantly flat-lying, with the exception of one locality in the center. Note that throughout the area the cleavage remains axial planar to $F_{1}$ folds.

To relate the above cleavage orientation variation to the deformation regime we make the assumption that cleavage planes approximate to the orientation of the $\lambda_{1} \lambda_{2}$-plane of the strain ellipsoid. Over the years the angular relationship between both planes has been the focus of lively discussion (e.g. Wood 1974, Hobbs et al. 1976, Williams 1976, Gray 1979); it is, however, probable that the angle is too small to be observed (e.g. Wilson 1984). For the purpose of this discussion, therefore, parallelism between both surfaces can reasonably be assumed. 

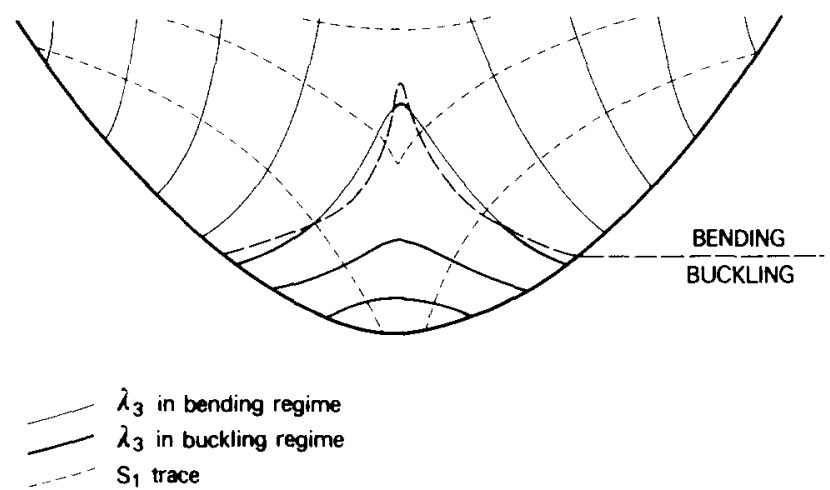

Fig. 8. The change in orientation of the $S_{1}$ trace and shortening $\lambda_{3}$ in the restored Yuso Basin. The transition from bending to buckling is marked by an arbitrary line (heavy dashes).

In Fig. 8 the trace of the regional cleavage in the synclinal structure is schematically illustrated (dashed lines). Consequently, the orientation of the maximum shortening direction, $\lambda_{3}$, changes from subvertical at the highest structural level to sub-horizontal at the lowest level. A model in agreement with these observations is presented below.

\section{Structural history of the Yuso Basin}

The formation of synclines as a result of basement subsidence along fundamental lines (e.g. Cardaño Line, Fig. 1) has earlier been suggested (Savage 1979, Heward \& Reading 1980). The overall deformation regime, therefore, is considered to be one of bending (i.e. passive folding with the main shortening direction subvertical). This regime is dominant at high structural levels $\left(\lambda_{3}\right.$ orientation in Fig. 8). Deeper into the structure the influence of the basin margins becomes important and movement is restricted. Hence $\lambda_{3}$ is less steeply plunging and we find the change from flap folds to cascade folds. In the lowest structural level, $\lambda_{3}$ has rotated to a subhorizontal orientation as a result of considerable space problems in the wedge shaped structure and sliding is no longer possible. Here, the dominant deformation regime is buckling, and parasitic folds with an upright cleavage are formed. Consequently, the change from bending to buckling regime occurs at depth in the structure; an arbitrary boundary $\left(\lambda_{3}\right.$ plunge of $\left.45^{\circ}\right)$ has been used in Fig. 8.

Subsidence and sedimentation continued during the formation of $F_{1}$ minor folds. Therefore, although $F_{1}$ folds represent the same deformation event, they could initiate at different levels and times, so that $F_{1}$ is not necessarily of the same age everywhere. Overprinting relationships, however, do not occur, so that $F_{1}$ is not a progressive deformation event.

Throughout the map area a difference in microfabric of the $S_{1}$ cleavage was not observed (Kaars-Sijpesteijn 1981, van der Pluijm 1981), which indicates that similar mechanisms were active. Individual folds, therefore, do not reflect a different deformation regime (bending vs buckling folds), other than a difference in orientation of the strain axes.

\section{Deformation regime}

From the relationships described above the following picture emerges. On the regional scale synclinal formation occurred in a bending regime. Within the syncline, however, this regime is only dominant at the higher structural levels. With increasing depth, buckling becomes the dominant deformation regime. On the smaller microfabric scale, on the other hand, a distinction between bending and buckling is not apparent. Consequently, the scale at which we investigate a particular structure will only reflect the deformation regime at that particular scale, i.e. the local deformation regime. Single outcrops, fold style, microfabric, etc. alone, therefore, do not necessarily provide information on the overall deformation regime.

\section{CONCLUSIONS}

The main conclusions presented in this paper on the development and significance of first deformation generation structures in greywackes from northern Spain are as follows.

(a) The Curavacas and Lechada synclines originally were part of a single west-plunging synclinal structure, the Yuso Basin; they are now separated by a late highangle fault.

(b) Three folding events have been recognized: (1) syn-sedimentary folding (pre- $F_{1}$ ), (2) $F_{1}$ folding and (3) $F_{2}$ fault-related folding. Two cleavages, $S_{1}$ and $S_{2}$, are present, axial planar to $F_{1}$ and $F_{2}$, respectively. The second cleavage is only locally developed; $S_{1}$ is present throughout the area.

(c) Three types of $F_{1}$ minor folds have been recognized: (1) flap folds, (2) cascade folds and (3) parasitic folds.

(d) The occurrence of these fold types is restricted to a specific structural level in the syncline. From top to bottom we find fold types (1)-(3), accompanied by a general steepening of the $S_{1}$ cleavage.

(e) The variation of $F_{1}$ structures in the syncline reflects the change from a bending to a buckling deformation regime with depth. The overall deformation regime, on the other hand, is bending. Furthermore, the microfabric of $S_{1}$ cleavage is independent of the position in the structure.

(f) The scale at which we study structures (e.g. folds, microfabrics) will only produce information on the deformation regime at that particular scale.

Acknowledgements - This research forms part of an ongoing project on the relationship between deformation and sedimentation in the Cantabrian Mountains of northern Spain. We would like to thank the Universities of Leiden, Utrecht and Michigan for financial assistance and drafting of the illustrations. B.v.d.P. would especially like to thank Professor Zwart and the University of Utrecht for their hospitality and support from October 1984 to June 1985. The paper benefited considerably from comments by Reinoud Vissers and two anonymous referees. Finally, we are grateful to the local population of our field areas for their hospitality, and for the wonderful weather. 


\section{REFERENCES}

Arthaud, F. \& Matte, P. 1977. Late Paleozoic strike-slip faulting in southern Europe and northern Africa: result of a right-lateral shear zone between the Appalachians and the Urals. Bull. geol. Soc. Am. $\mathbf{8 8}, 1305-1320$

Borradaile, G. J. 1976. "Structural facing" (Shackleton's rule) and the Paleozoic rocks of the Malaguide complex near Vélez Rubio, SE Spain. K. ned. Ac. Wetensch. 79, 330-336.

de Sitter, L. U. 1964. Structural Geology (2nd edn). McGraw-Hill, New York.

Gray, D. R. 1979. Microstructure of crenulation cleavages: an indicator of cleavage origin. Am. J. Sci. 279, 97-128.

Harrison, J. V. \& Falcon, N. L. 1934. Collapse structures. Geol. Mag. 71, 529-539

Harrison, J. V. \& Falcon, N. L. 1936. Gravity collapse structures and mountain ranges, as exemplified in south-western Iran. $Q . J / G e o l$. Soc. Lond. 92, 91-102.

Heward, A. P. \& Reading, H. G. 1980. Deposits associated with a Hercynian to late Hercynian continental strike slip system, Cantabrian Mountains, Northern Spain. In: Sedimentation in Oblique slip Mobile Zones (edited by Ballance. P. F. \& Reading, H. G.). Spec. Publs Int. Ass. Sediment. 4, 105-125.

Hobbs, B. E., Means, W. D. \& Williams, P. F. 1976. An Outline of Structural Geology. J. Wiley, New York.

Julivert, M. 1971. Décollement tectonics in the Hercynian Cordillera of northwest Spain. Am. J. Sci. 270, 1-29.

Kaars-Sijpesteijn, C. H. 1981. Structureel metamorfe ontwikkeling van de Lechada syncline, Cantabrisch Gebergte. Provincie LeonSpanje. Unpubl, 'doktoraal' thesis, Leiden, Utrecht.

Kanis, J. 1956. Geology of the eastern zone of the Sierra del Brezo (Palencia, Spain). Leid. geol. Meded. 21, 375-445.

Koopmans, B. N. 1962. The sedimentary and structural history of the Valsurvio Dome (Cantabrian Mountains, Spain). Leid. geol. Meded. 26, 121-232.

Lobato Astorga, L. 1977. Geologia de los valles altos de los rios Esla Yuso, Carrion y Deva. Unpubl. Ph.D. thesis, Oviedo.

Maas. K. 1974. The geology of Liebana, Cantabrian Mountains, Spain; deposition and deformation in a flysch area. Leid. geol. Meded. 49, 379-465.
Maas, K. \& van Ginkel, A. C. 1983. Variscan olistostrome deposition and synsedimentary nappe emplacement, Valdeon area, Cantabrian Mountains, Spain. Leid. geol. Meded. 52, 341-381.

Oriol, R. 1876. Description geologico-industrial de le cuenca hullera del rio Carrion de la provincia Palencia. Boln. Comn. Mapa geol. Esp. 3, 137-168.

Reading, H. G. 1970. Sedimentation in the Upper Carboniferous of the southern flanks of the Central Cantabrian Mountains, Northern Spain. Proc. Geol. Ass. 81, 1-41.

Savage, J. F. 1967. Tectonic analysis of Lechada and Curavacas synclines, Yuso Basin, NW Spain. Leid. geol. Meded. 39, 193-247.

Savage, J. F. 1979. The Hercynian orogeny in the Cantabrian Mountains, N Spain. Krystallinikum 14, 91-108.

Savage, J. F. \& Boschma, D. 1980. Geological maps of the southern Cantabrian Mountains (Spain). Leid. geol. Meded. 50, 75-114.

Tobisch, O. T. 1984. Development of foliation and fold interference patterns produced by sedimentary processes. Geology 12, 441-444. van der Pluijm, B. A. 1981. Strukturele geologie, illiet kristalliniteit en cleavage ontwikkeling van een gebied in het Cantabrisch Gebergte, prov. Palencia. Unpubl. 'doktoraal' thesis, Leiden, Utrecht.

van Ginkel, A. C. 1965. Carboniferous fuselinids from the Cantabrian Mountains (Spain). Leid. geol. Meded. 34, 1-225.

van Veen, J. 1965. The tectonic and stratigraphic history of the Cardaño area, Cantabrian Mountains, northwest Spain. Leid. geol. Meded. 35, 45-104.

Wagner, R. H. \& Martinez-Garcia, E. 1974. The relation between geosynclinal folding phases and foreland movements in northwest Spain. Studio Geol. 7, 131-158.

Williams, P. F. 1976. Relationships between axial plane foliations and strain. Tectonophysics 39, 305-328.

Williams, P. F., Collins, A. R. \& Wiltshire, R. G. 1969. Cleavage and penecontemporaneous deformation structures in sedimentary rocks. J. Geol. 77, 415-425.

Wilson. C. J. L. 1984. Shear bands, crenulations and differentiated layering in ice-mica models. J. Struct. Geol. 6. 303-319.

Wood, D. S. 1974. Current views on the development of slaty cleavage. Ann. Rev. Earth Planet. Sci. 2, 369-401. 